\title{
THREE MANUSGRIPT PRECURSORS OF VIDIUS'S CHIRURGIA
}

by

\author{
WILLIAM BROGKBANK, M.D., F.R.G.P.
}

VIDIus's Chirurgia è Graeco in Latinum conversa was published in Paris under the auspices of the King of France in 1544 (Fig. I). ${ }^{3}$ It was by far the best illustrated work on surgery that had up to then been published. Castiglioni has described it as 'the first surgical work published with fine illustrations' ${ }^{4}$

The translations were of six works by Hippocrates, one by Galen and two by Oribasius with commentaries by Galen and by Vidius himself (Fig. 2). The originals are in Greek manuscript, and are a treasured possession of the Laurenzian Library in Florence ${ }^{1}$ (Fig. 3). They had been made by a Byzantine

C H I R V R G I A ¿Grxcoun Latinum conuerfa, VidoVidioFlorentmointerpreete,cum nonnullis eculdem Vidij cō. mentarijs.

Indicem suctorum \& operum feynentip pugmi quaxrito.

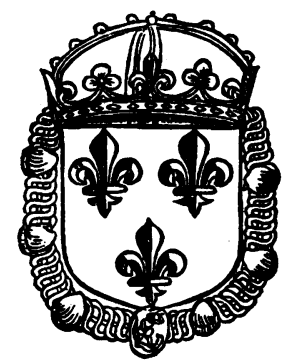

Cum privilegijs Rom.Pontificis,

GALLIARVMREGIS, ET DVCIS Ferrariz, quorum exemplum indici librorum fubiecimus.

Excudebat Petritr Gakerius Lucetiz Parifiorum, pridie Calendas Maij.

M. D. XIIIIL

Fig. I

Title-page of Vidius's Chirurgia. physician, Nicetas. Some of the manuscripts were accompanied by pictures for instructive purposes, notably thirty fullsized plates illustrating the commentary of Apollonius of Kitium on the Hippocratic treatise on dislocations and many smaller pictures scattered through the pages of Galen's treatise on bandaging. They are pen and brush drawings, illustrating the various manipulations and apparatus used in reducing dislocations and fractures, the dark brown figures in each case being surmounted by an archway of ornate and highly coloured Byzantine design. The original from which the tenth-century copy was made could only have existed in the form of a roll. When at a later date the roll was transformed into a manuscript volume the arch would be added to allow the picture to fill a full page. These additions by no means always fit the illustration as is shown in the picture of a patient undergoing treatment for kyphosis. Notice how the two kneeling men overlap the columns and do not fit into the space within the arch. Clearly the arch was added at a later date (Fig. 8).

I9I 


\title{
William Brockbank
}

The manuscripts probably go back to Alexandria or Cyprus, where Apollonius wrote his commentary between the years 85 and $5^{1}$ B.C. It is likely that the illustrations were made during or shortly after his lifetime. The Galen illustrations date from the second century A.D. They were undoubtedly transcribed direct from antiquity and therefore represent the genuine Hippocratic traditions of surgical practice as transmitted through later Greek channels to Byzantium.?

This transcript fell into Turkish hands at the sack of Constantinople. It was bought in Crete in 1495 and brought to Florence by the Greek scholar Joannes Lascaris (c. 1445-I 535), who acted as an intermediary between Lorenzo the Magnificent and the Sultan Bayezid II. Many other valuable manuscripts reached Italy in the same way. ${ }^{\circ}$

The chief glory of the Chirurgia lies in its woodcuts, although no reference is made to the artist. But elsewhere Vidius gives two names. It happens that part of Vidius's original manuscript and drawings have been preserved in the National Library in Paris, in book form in two volumes (Fig. 4). ${ }^{2}$ The first two translations are missing. The third on wounds of the head is in a separate volume. The remaining six are freely illustrated and are beautifully bound in gold tooled leather-a lovely book to handle. The manuscript is identical with the book except for a few minor alterations and a note to the reader preceding each of the books translated. That which precedes the De Machinamentis of Oribasius provides the following information:

\section{Index auctorum \& operum.}

\author{
De vlceribus. \\ De fiftulis. \\ Hippocratis. De vulneribus capitis. \\ cum Vidij in fin- \\ gulos libros com - \\ De fracturis; cum II I.Galeni commmentariis. \\ Liber \\ De articulis, cum IIII. Galeni commentariis. \\ Oribafij. E Ee De laqueis. \\ De officinâ medici,cú IIII. Galeni commentariis.
}

Fig. 2

Contents of the Chirurgia.

In the interpretation of these machines I was keen not only to understand what was written but also to depict and to make models in wood so that I can give a better idea of them than by description and could set them as it were before the eyes of men. Apart from several others Joannes Santurineus of Rhodes, a friend of my cardinal, is my witness. So, too, is Francesco Primaticcio of Bologna the celebrated painter who works for the King of France. I have used their work on occasions."

Unfortunately the statement is no clearer than that.

There is also a note on the difficulty in making the translation: 

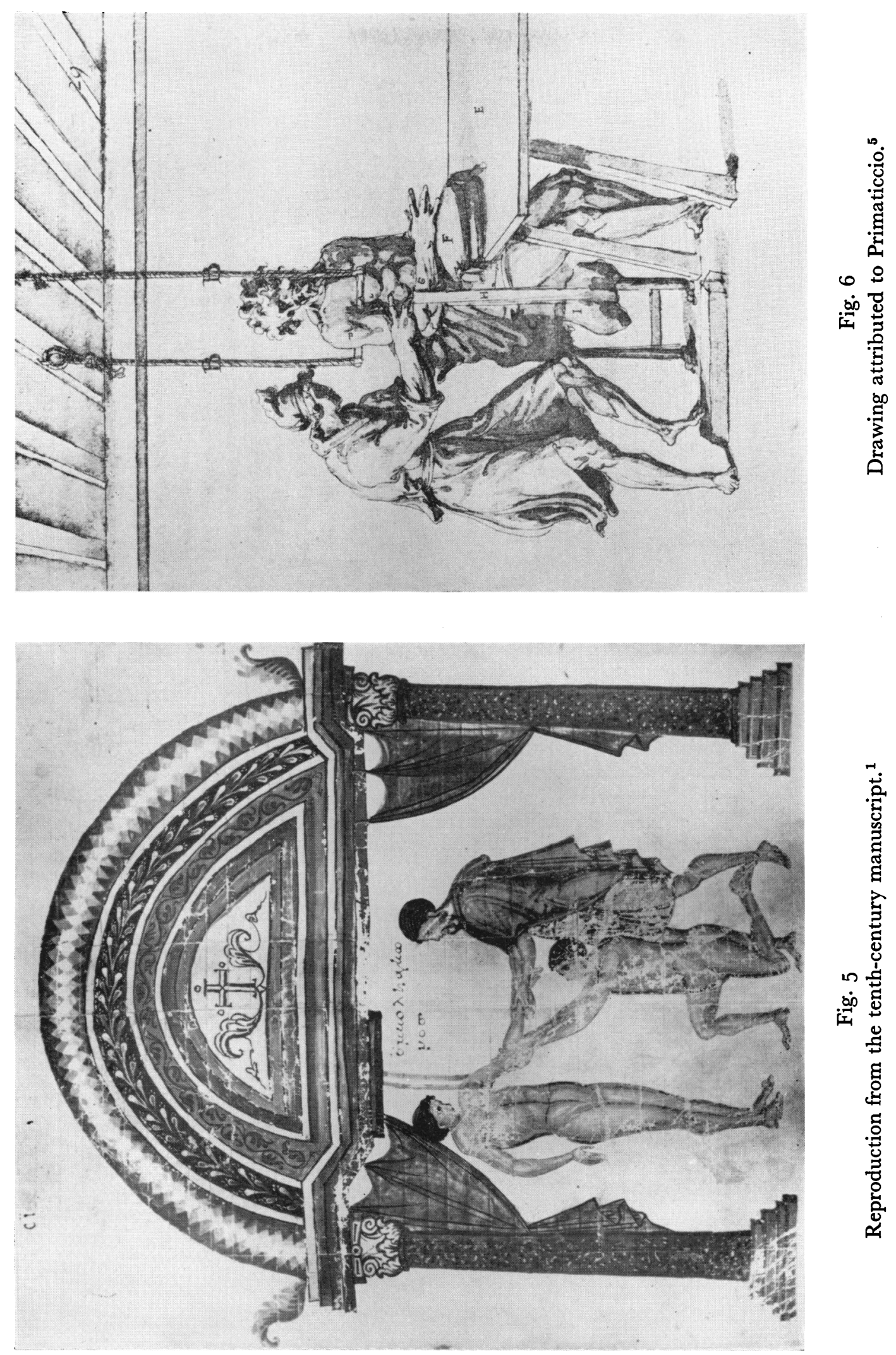


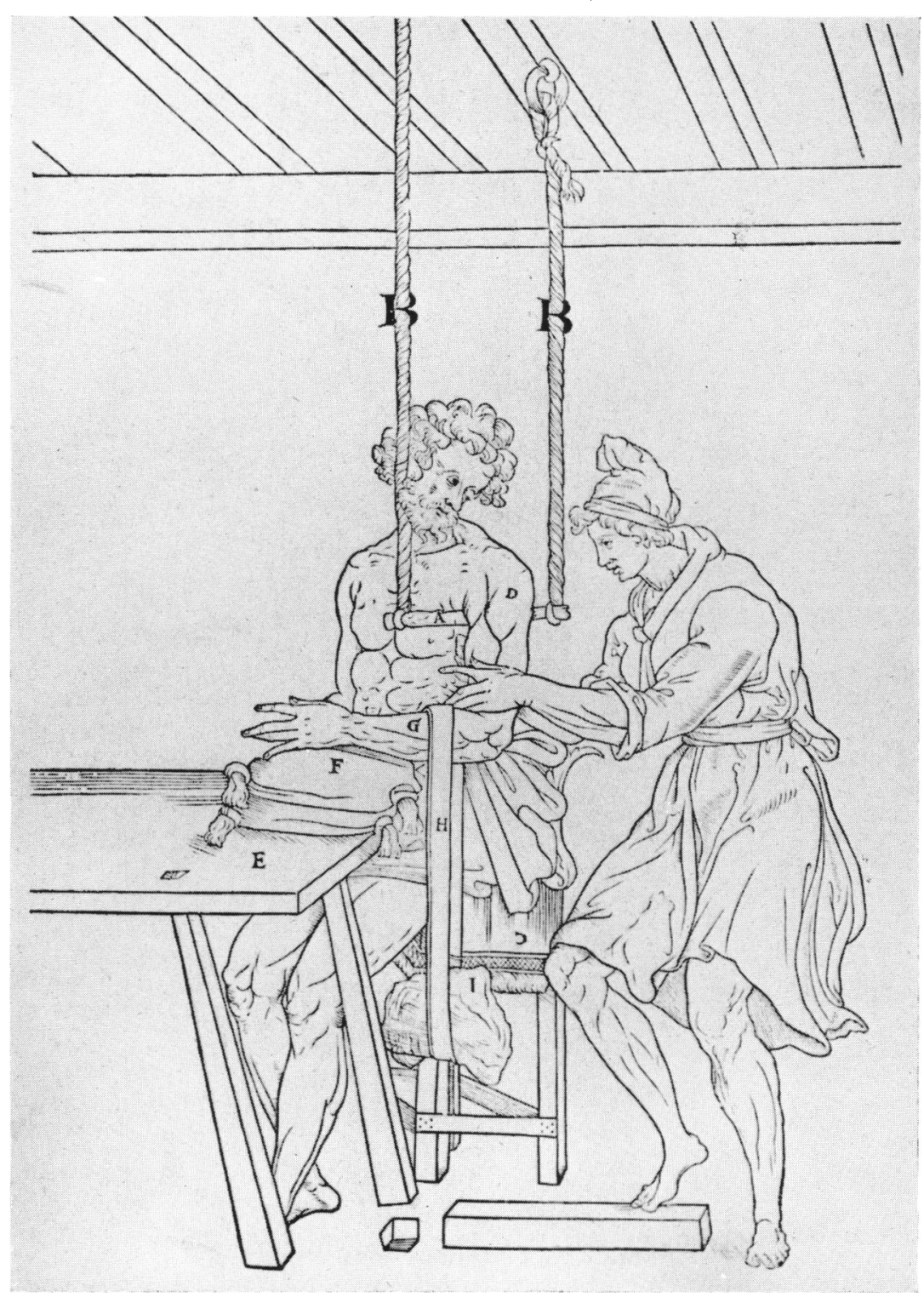

Fig. 7

Vidius's Chirurgia. 

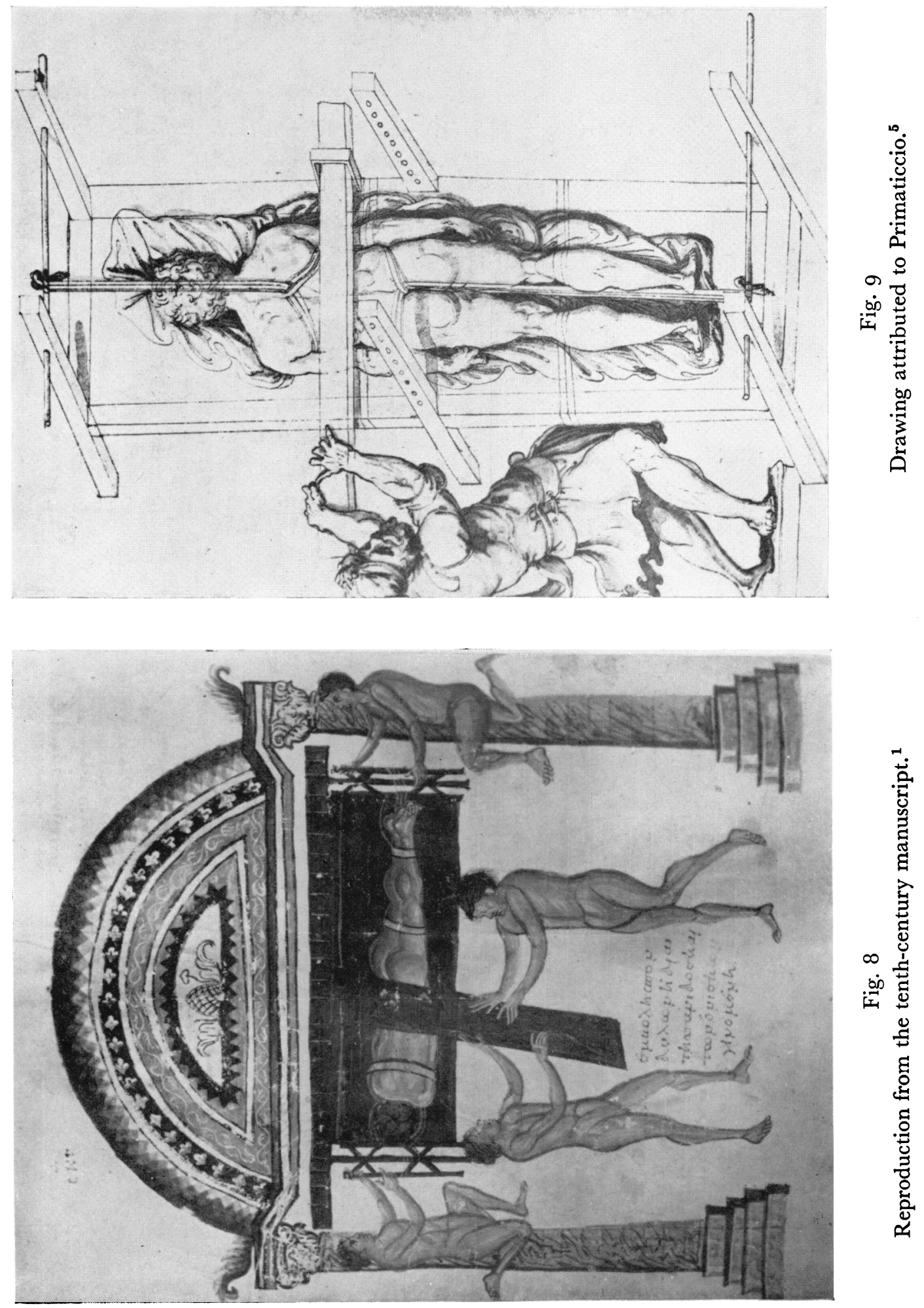

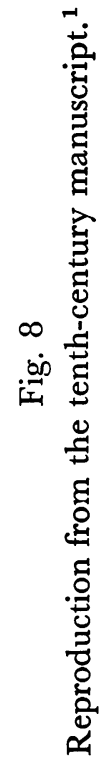




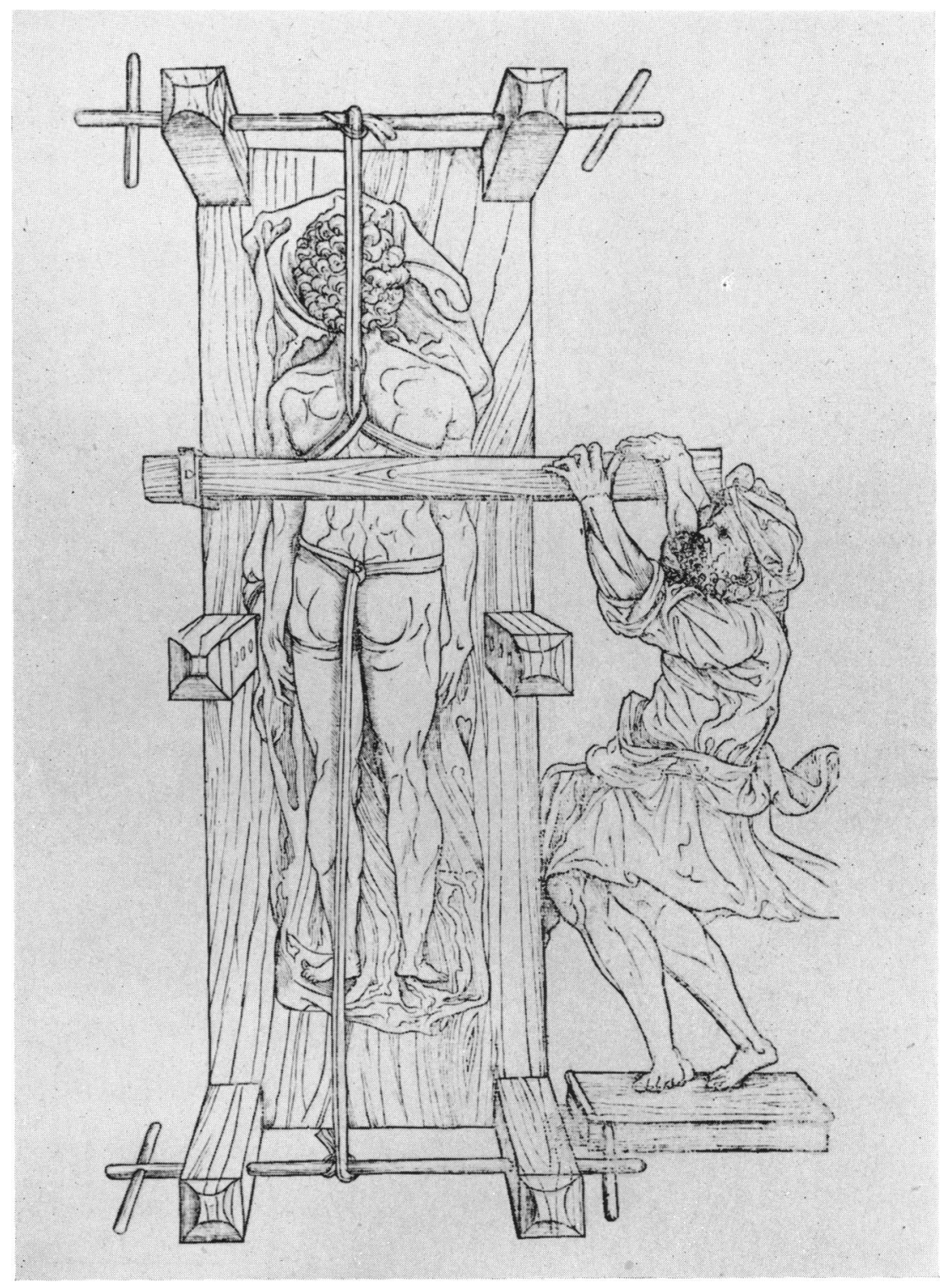

Fig. 10

Vidius's Chirurgia. 


\section{Three Manuscript Precursors of Vidius's Chirurgia}

But since the codices were full of corruptions there was need of much emendation. Notable for this, apart from his matchless knowledge of Greek, is Matthias Corcireus a pupil of the great Joannes Lascaris. I am amazed at the facility of his work. ${ }^{5}$

The artist, presumed to be Primaticcio, was not content with reproducing the ancient drawings which had suffered considerable damage. He very happily interpreted and clarified them in what was to him the modern idiom, and he amended the surgical apparatus presumably on the advice and guidance of Vidius, giving in his drawings minute mechanical details. ${ }^{5}$ Vidius deserves much credit for choosing such a fine draughtsman and guiding his pen so skilfully. Many of the illustrations were entirely original.

$\mathrm{He}$ also deserves the greatest credit for his selection of a craftsman to make the woodcuts. They are mirror images of the original drawings which had to be copied in simplified form on to the blocks. The blocks had then to be reversed for printing. The woodcuts are of excellent workmanship and are very numerous. They were probably done by François Jollat.

The text and most of the illustrations of the tenth-century manuscript are well preserved. It is most interesting to compare the illustrations with those that so plentifully decorate the pages of the Vidian manuscripts and with the woodcuts in the Chirurgia. Two groups of pictures are shown here (Figs. 5-10).

The first illustrates the treatment of a fractured humerus, extension being applied by a sling from the roof to the axilla and - so far as Vidius is concerned-by a heavy boulder suspended from the forearm, the hand being supported by a cushion on the table. Could anything be clearer in detail? The operator seems to be correcting lateral displacement. The Vidian method is clearly an improvement on the technique shown in the tenth-century drawing.

The second group illustrate the brutal method employed in the treatment of kyphosis. The spine was put on traction by means of

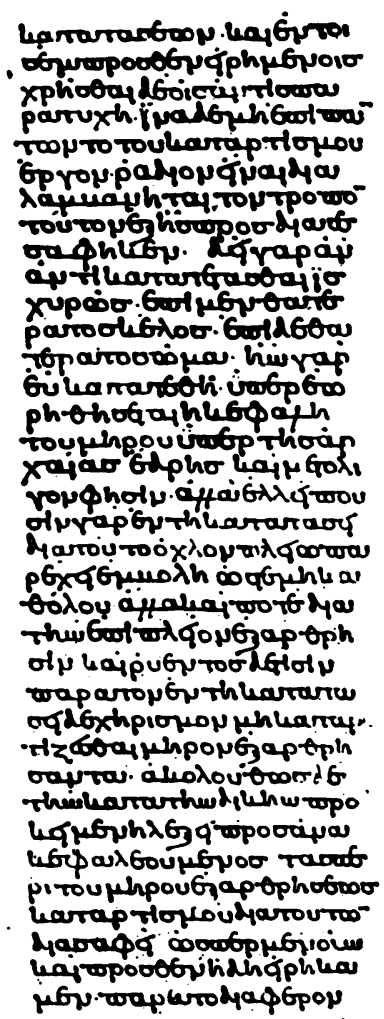

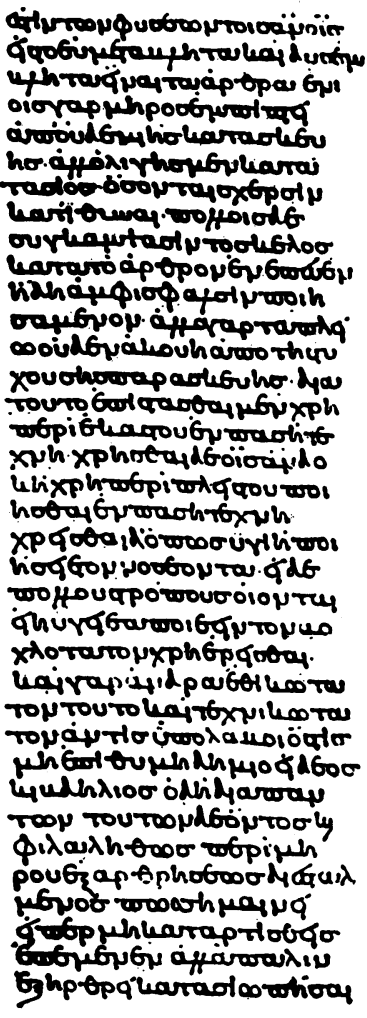

Fig. 3

The tenth-century manuscript. ${ }^{1}$

193 


\section{William Brockbank}

leather thongs and a pair of windlasses. A beam was then pivoted in a hole in the wall beside the patient or from part of the operator's bench. It was then used as a lever to force the apex of the deformity into place.

Hippocrates was doubtful about the efficacy of this method. He stressed the necessity for careful padding between the beam and the patient's spine, and said that the operators must be experienced and cautious 'for it is so powerful a method that it is more suitable for an instrument of torture and not for medicine'. But he added that he knew of no other better way of applying pressure. ${ }^{3}$

Comparison of the three drawings is interesting. In the old manuscript the windlasses seem fragile and two men are applying gentle pressure on the beam. The Primaticcio drawing shows something more like the medieval rack in use with one man only applying pressure. The perspective is curious. The final woodcut shows a more sturdy machine. It is noteworthy that in none of the pictures is Hippocrates's plea being observed for careful padding between the beam and the spine.

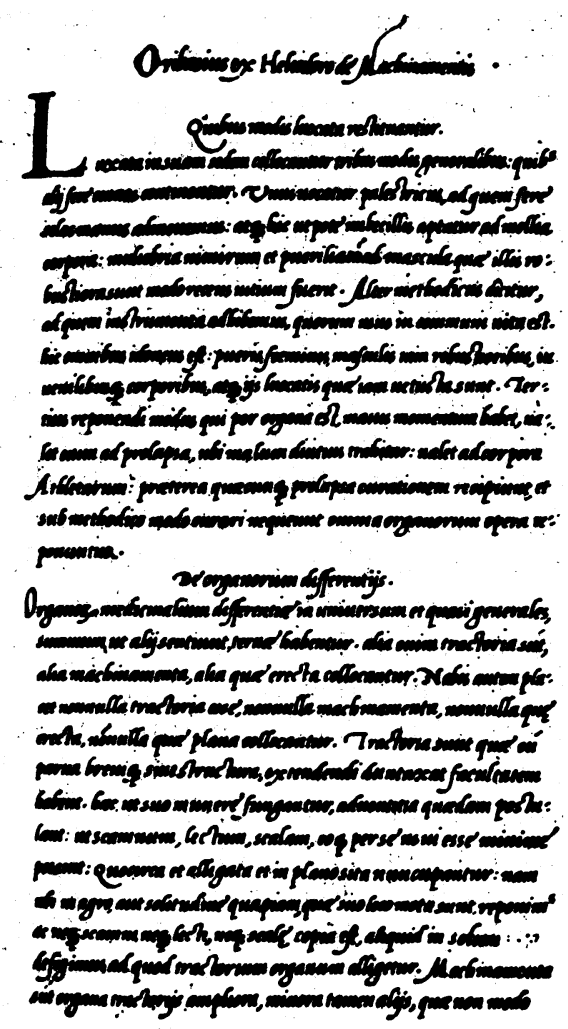

Fig. 4

Vidius's manuscript. ${ }^{2}$

\section{ACKNOWLEDGEMENTS}

I am much indebted to Mr. O. R. Corbett, B.A., Mr. J. Lingard, B.A., Mr. D. Lloyd Griffiths, F.R.C.s., the Department of Medical Illustration of the Manchester Royal Infirmary and its Director, Dr. R. Ollerenshaw.

I am most grateful to the Directress, Biblioteca Medicea Laurenziana, Firenze, for permission to reproduce Figs. 3,5 and 8 and to the Director of the Bibliotheque Nationale, Paris, for permission to reproduce Figs. 4,6 and 9 .

\section{BIBLIOGRAPHY}

I Biblioteca Medicea Laurenziana, Firenze, Plut. Lxxrv, 7 .

2. Bibliothique Nationale, Paris, Latin 686r and 6866.

3. Brock BA NK, W., Ann. Roy. Coll. Surg. Eng., 1956, xIx, 269-95.

4. Gastiglioni, A., Italian Medicine, New York, 1932, pp. 51-3.

5. Collection des chirurgiens grecs avec dessins attribués au Primatice, 1908, Paris.

6. Osle R, W., Bibliotheca Osleriana, 1929, Oxford, p. 13.

7. Weitzmann, K., Illustrations in roll and codex, Princeton, 1947, pp. 74, 108. 